\title{
СТАТЬИ
}

UDC 347.447

\section{Characteristics of modern European contract law}

\author{
Reiner Schulze
}

For citation: Schulze, Reiner. 2020. Characteristics of modern European contract law. Pravovedenie 64 (2): 201-221. https://doi.org/10.21638/spbu25.2020.201

European contract law has recently entered a new phase in its development as a result of the introduction of new legislation responding to the challenges posed by digitalization and, in particular, the supply of digital content and digital services. Whereas the new legislation contains several characteristics which reflect a continuity of concepts already well-established in European contract law, several innovations have been necessary in order to take account of the specific features of these digital products and the manner in which they are supplied. The legislative responses will play a pivotal role not only in consumer protection but for European contract law. This article will focus in particular on two new "twin" directives: Directive 2019/770 on certain aspects concerning contracts for the supply of digital content and digital services and Directive 2019/771 on certain aspects concerning contracts for the sale of goods. In examining the core features of these two Directives, this article will consider how their new and innovative characteristics which respond to the challenges of digitalization can contribute towards a modern European contract law. These new approaches in European legislation clearly show that the further development of contract law is facing challenges that go beyond this area of law. The modernization of contract law therefore raises questions that must ultimately be directed at clarifying the overarching features of European private law as a whole. Finally, the relationship between the law of obligations, on the one hand, and property law or intellectual property law, on the other, and possibly a new definition of the boundaries and interaction between these areas, can be considered if contract law recognizes data as an asset, but it will not be able to guarantee sufficient protection of these assets with its instruments alone. Embedding the new concepts, principles and rules in the field of contract law in the development of private law as a whole, in line with the changes in the "digital age", will therefore remain a major task for legislation and legal doctrine in the EU and beyond.

Keywords: contract law, contract terms, consumer law, consumer protection, data, digitalization, European Union law.

\section{Introduction}

European contract law has recently entered a new phase in its development. Starting from the "Digital Single Market Strategy" ${ }^{1}$ presented by the European Commission in 2015, the European Union (further on - EU) has since passed several pieces of legisla-

Reiner Schulze - Dr. iur., Professor, Dr. h. c., University of Münster, School of Law, 14-16, Universitätsstr., Münster, 48143, Germany; reiner.schulze@uni-muenster.de

1 COM (2015) 192 final.

(c) St. Petersburg State University, 2021 
tion in response to challenges posed by digitalization. The legislation concerns various aspects of private law (including business law) and public law (including data protection). In this respect the European legislator has once more initiated an extensive modernization of contract law. Already in the three decades before, the first phase in the development of European contract law contained a number of new characteristics in comparison to the traditional contract law in national codifications and thus gave sustained stimuli to the law of the Member States. Since 2015, however, several EU directives and regulations have commenced a new phase that is characterized by the adaptation of European contract law to the far-reaching changes resulting from digitalization. This legislation changes the legal landscape by including provisions responding to the role of data in contracting, the structure of contractual obligations with regard to digital content, the structure of the remedies, and unwinding terminated contracts.

\section{The first phase of modernization}

\subsection{Overview}

The initial legislative measures from the European Economic Community (from which the European Union later emerged) often concerned matters of public law, however the focus on the significance of private law for the internal market gradually increased ${ }^{2}$. Since the 1980s the European legislator directed greater attention to contract law (in particular in consumer contract law with the Doorstep Selling Directive ${ }^{3}$ and in commercial law with the Commercial Agents Directive ${ }^{4}$ ). The volume of European legislation in the following decades greatly and rapidly increased, covering further aspects of contract law, such as consumer credit ${ }^{5}$, unfair contract terms in consumer contracts ${ }^{6}$, guarantees in consumer sales $^{7}$, e-commerce ${ }^{8}$, late payment ${ }^{9}$, and also protection against discrimination ${ }^{10}$.

2 See: Hallstein W. Angleichung des Privat- und Prozessrechts in der Europäischen Wirt-schaftsgemeinschaft // Rabels Zeitschrift für ausländisches und internationales Privatrecht. 1964. Bd. 28 (2). S. 211.

3 Council Directive 85/577/EEC of 20 December 1985 to protect the consumer in respect of contracts negotiated away from business premises OJ $L 372,31.12 .1985,31$, since repealed by Directive 2011/83/EU of the European Parliament and of the Council of 25 October 2011 on consumer rights OJ L 304, 22.11.2011, 64.

${ }^{4}$ Council Directive 86/653/EEC of 18 December 1986 on the coordination of the laws of the Member States relating to self-employed commercial agents OJ L 382, 31.12.1986, 1.

5 Council Directive 87/102/EEC of 22 December 1986 for the approximation of the laws, regulations and administrative provisions of the Member States concerning consumer credit OJ L 42, 12.02.1987, 48, since repealed by Directive 2008/48/EC of the European Parliament and of the Council of 23 April 2008 on credit agreements for consumers OJ L 133, 22.05.2008, 66.

${ }^{6}$ Council Directive 93/13/EEC of 5 April 1993 on unfair terms in consumer contracts OJ L 95, 21.04.1993, 29 ("Unfair Terms Directive").

7 Directive 1999/44/EC of the European Parliament and of the Council of 25 May 1999 on certain aspects of the sale of consumer goods and associated guarantees OJ L 171, 07.07.1999, 12 ("Consumer Sales Directive"), since repealed by Directive (EU) 2019/771 of the European Parliament and of the Council of 20 May 2019 on certain aspects concerning contracts for the sale of goods OJ L 136, 22.05.2019, 28 ("Sale of Goods Directive").

8 Directive 2000/31/EC of the European Parliament and of the Council of 8 June 2000 on certain legal aspects of information society services, in particular electronic commerce, in the Internal Market OJ L 178, 17.07.2000, 1.

9 Directive 2000/35/EC of the European Parliament and of the Council of 29 June 2000 on combating late payment in commercial transactions OJ L 200, 08.08.2000, 35, since repealed by Directive 2011/7/EU of the European Parliament and of the Council of 16 February 2011 on combating late payment in commercial transactions OJ L 48, 23.02.2011, 1.

10 Council Directive 2004/113/EC of 13 December 2004 implementing the principle of equal treatment between men and women in the access to and supply of goods and services OJ L 373, 21.12.2004, 37 . 
This European legislation is based on the provisions in the underlying Treaties ${ }^{11}$ (and their predecessors) which set the tasks and competences for these European Communities. EU Regulations have immediate effect as harmonized law in the entire Union. In contrast, directives require transposition by the Member States into national law, whereby the Member States are free to choose the form and method (approximation as opposed to unification). Member States may, for example, transpose consumer contract law directives by introducing a new, separate piece of legislation, by introducing rules into the civil code (such as in Germany and the Netherlands) or in a consumer code (such as in France and Italy). With regard to interpretation, the decisions of the Court of Justice of the European Union (further on - CJEU) are binding on the courts and authorities in the Member States. Provisions of EU law (including the interpretation thereof) take priority; a conflicting provision of national law will, in principle, therefore not apply.

In the EU, national contract law thus exists alongside a European contract law that is either directly applicable and uniform or has been shaped by the Member States in transposing the rules into their national law. Some Member States have also voluntarily extended the scope of EU directives to other areas of law thereby enlarging the effect of EU law. Despite such far-reaching effects, the European legislator has not aimed to create a full and structurally self-contained law of contract. The individual legislative measures have rather been a response to current challenges for the internal market in a particular area and were led by political priorities; a comprehensive plan was lacking. Such measures have therefore been described as "fragmented", "pointillistic" and in part also contradictory ${ }^{12}$. The European Commission's proposal for a Common European Sales Law ${ }^{13}$ (in a comprehensive and systematic form) failed due to opposition from several Member States ${ }^{14}$. A "coherent European contract law" 15 is therefore a matter which has been achieved to a small extent even though the Treaty on the Functioning on the European Union provides that the EU shall ensure consistency between its policies and activities ${ }^{16}$, and despite the proposals and models in various academic drafts ${ }^{17}$.

\subsection{Innovative approaches}

In spite of its incomplete nature and insufficient consistency, European legislation had already inspired national laws before - in a second phase - turning to the legal consequences of digitalization. This section will give a few illustrative examples.

11 See: Treaty on European Union OJ C 2002, 07.06.2016, 1 (TEU); Treaty on the Functioning of the European Union OJ C 202, 07.06.2016, 47 (further on - TFEU); Charter of Fundamental Rights of the European Union OJ C 202, 07.06.2016, 389. For the text of the founding treaties and other treaties see: https:// eur-lex.europa.eu/homepage.html (accessed: 14.10.2020).

12 See: Eidenmüller H. et al. Der Gemeinsame Referenzrahmen für das Europäische Privatrecht // JuristenZeitung. 2008. Bd. 63 (11). S. 529-530; Honsell H. Die Erosion des Privatrechts durch das Europarecht // ZIP: Zeitschrift für Wirtschaftsrecht. 2008. Bd. 29 (14). S.630; Kötz H. Europäisches Vertragsrecht. Tübingen: Mohr Siebeck, 2015. S. 12; Schulze R. European Private Law and Existing EC Law // European Review of Private Law. 2005. Vol. 13 (1). P. 4; Twigg-Flesner C. Introduction // The Cambridge Companion to European Union Private Law / ed. by C. Twigg-Flesner. Cambridge: Cambridge University Press, 2010. P. 8.

13 COM (2011) 635 final.

14 See COM (2014) 910 final.

15 COM (2003) 68 final.

16 Art. 7 TFEU.

17 See, inter alia: Principles of European Contract Law / eds O. Lando, H. Beale. Alphen aan den Rijn: Kluwer, 1999; Principles of the Existing EC Contract Law (Acquis Principles) - Contract II / Acquis Group. Munich: Sellier, 2009; Draft Common Frame of Reference - Full Edition / eds C. von Bar, E. Clive. Munich: Sellier, 2009. 


\subsection{Preventative approach}

As is typically the case for the contract laws of the Member States, European contract law follows the principles of private autonomy and freedom of contract. However, in contrast to the original approach in the civil codes of several Member States, EU law also considers other principles and Leitgedanke which can limit contractual freedom. These Leitgedanke emerge in particular from the tasks for the EU, which are anchored in the Treaties as individual "policy" fields, such as the protection against particular types of discrimination ${ }^{18}$, data protection ${ }^{19}$, encouraging the development of small and medium-sized enterprises ${ }^{20}$, and especially consumer protection ${ }^{21}$. In contrast to the civil codes from the $19^{\text {th }}$ century and early $20^{\text {th }}$ century, European contract law thus focuses more greatly on using prevention as a means to steer market behaviour.

With regard to the aforementioned protective purposes, EU legislation has developed a number of legal instruments which combat the asymmetry between the parties when concluding or performing a contract (such as protecting the weaker party with pre-contractual information, withdrawal rights, transparency requirements, and mandatory rules). In addition, EU legislation provides sanctions beyond mere compensation in order to prevent undesirable market behaviour, for instance for reasons of consumer protection (e. $\mathrm{g}$. exempting the consumer from paying any consideration in instances of inertia selling ${ }^{22}$ ). Such provisions on guiding market behaviour have become a key feature of the development of modern private law ${ }^{23}$ and have influenced the development of the law in the EU Member States.

\subsection{Formation of contract}

The European legislator has not created a full set of rules for the formation of contract but rather just specific rules for particular aspects, such as consumer protection, e-commerce, and commercial agency contracts. Nonetheless, viewing each of these individual rules as a whole allows one to recognize a process for the conclusion of contract.

From this perspective contracts are not only concluded on the basis of a single "magic moment" 24 in which an offer is accepted. Pre-contractual obligations instead initiate the process of contract formation ${ }^{25}$. Following acceptance, a right of withdrawal puts the contract in a state of limbo due to the mandatory withdrawal period (such as in distance or off-premises contracts ${ }^{26}$ or in consumer credit contracts $\left.{ }^{27}\right)^{28}$. The withdrawal period

18 Arts 8 and 10 TFEU.

19 Art. 16 TFEU.

20 Art. 173 TFEU.

21 Arts 12 and 169 TFEU.

22 Art. 27 Directive 2011/83/EU. The consumer neither has to pay compensation for any damage caused to the unsolicited good nor for his enrichment. For details see: Schulze R., Zoll F. European Contract Law. Fully revised $3^{\text {rd }}$ ed. Baden-Baden: Nomos, 2021. Ch. 3. P. 92 et seq.

${ }^{23}$ See: Wagner G. Prävention und Verhaltenssteuerung durch Privatrecht // Archiv für die civilistische Praxis. 2006. Bd. 206 (2/3). S. 352; Janssen A. Präventive Gewinnabschöpfung. Tübingen: Mohr Siebeck, 2017. S. 27 et seq., 67 et seq.; Schulze R. The New Challenges in Contract Law // New Features in Contract Law / ed. by R. Schulze. Munich: Sellier, 2007. P. 6 et seq.

${ }_{24}$ Pfeiffer T. New Mechanisms for Concluding Contracts // New Features in Contract Law / ed. by R. Schulze. P. 161.

25 In particular the pre-contractual information duties under Art. 5 et seq. Directive 2011/83/EU and other Directives.

${ }^{26}$ Art. 9 et seq. Directive 2011/83/EU.

27 Art. 14 and 15 Directive 2008/48/EC.

28 On the controversial mandatory nature of withdrawal rights see: Eidenmüller $\mathrm{H}$. et al. Der Gemeinsame Referenzrahmen für das Europäische Privatrecht. S. 529 et seq.; Wagner G. Mandatory Contract Law: 
may even extend to one year if the trader does not (correctly) inform the consumer of the right of withdrawal ${ }^{29}$. The conclusion of contract through the acceptance of an offer is therefore anchored in a prior phase, in which obligations relating to the contract may exist, and in a subsequent phase, in which the existence of the contract may depend on the nonexercise of a right of withdrawal. European contract law thus follows a notion of contract formation that does not revolve around a single moment but rather takes into account a process comprises of several steps. In this respect there are parallels to the discussions in modern business law on the "gradual formation of contract" with instruments such as a letter of intent or heads of agreement ${ }^{30}$.

\subsection{Control of contract terms}

The Unfair Terms Directive, with its judicial control of unfair contract terms in consumer contracts, emerged at an early stage in the development of European contract law. The Directive uses a substantive standard to restrict the freedom of the parties to stipulate the terms of the contract: terms are unfair if, contrary to the requirement of good faith, they cause a significant imbalance in the parties' rights and obligations arising under the contract, to the detriment of the consumer. This standard applies only to terms that have not been individually negotiated ${ }^{31}$. The approach shows how European contract law addressed a problem that can arise where parties do not have equal bargaining power - a problem which can arise in e-commerce no less than in traditional forms of contracting - and which in national legal traditions are commonly referred to with expressions such as "contrat d'adhesion" or "standard term contracts". The European legislator, however, did not consider at the time that the problem is not specific to consumer contracts as unequal bargaining power can also arise in commercial standard term contracts ${ }^{32}$.

\subsection{Content of contracts}

The new concept of "legitimate" or "reasonable" consumer expectations has gained a central role in shaping the content of contracts, in particular through the Consumer Sales Directive. The content of the contract and the resulting performance obligations are greatly shaped by what the consumer may reasonably expect ${ }^{33}$. In this respect, the traditional view that the parties determine the content of their contract is modified in European contract law by the consideration of what a party may reasonably expect, irrespective of whether and how this party expressed such expectations when negotiating the contract ${ }^{34}$.

The concept of "reasonable expectations" includes statements on the specific characteristics of the goods that were not directly expressed in the negotiations, but which were made prior to the conclusion of the contract, such as in advertising. This is not limited to statements made by the seller as it can also encompass statements from earlier links in the contractual chain (including the producer). The binding effect of pre-contractual public statements can thus extend to statements made by third parties. This thus impacts

Functions and Principles in Light of the Proposal for a Directive on Consumer Rights // Erasmus Law Review. 2010. Vol. 3 (1). P. 47 et seq. - See also: Schulze R., Zoll F. European Contract Law. Ch. 3. P. 135-136.

29 Art. 10 Directive 2011/83/EU.

30 See also: Schulze R., Zoll F. European Contract Law. Ch. 2. P. 71-73.

31 Art. 3 (1) Directive 93/13/EEC.

32 See: Judicial Review of Commercial Contracts / eds T. Pfeiffer, H. Wais. Munich: C. H. Beck, 2021.

${ }^{33}$ Art. 2 (2) (d) Directive 1999/44/EC; Art. 7 (1) (d) Directive 2019/771.

34 Schulze R., Zoll F. European Contract Law. Ch. 2. P. 10. 
on the principle of privity of the contractual rights and duties as the content of the duties is not determined solely by the parties themselves. European contract law therefore takes into account the widespread collaboration in marketing goods and services: advertising, labelling and other marketing measures affecting the final buyer are often not undertaken by the final seller (especially where mass-market products are concerned) but instead (and sometimes even almost entirely) by the producer, importer or a distributor. The final seller can benefit from these measures in contracting with the consumer, yet at the same time must accept the consequences ${ }^{35}$.

\subsection{Conformity and consequences of non-conformity}

The consideration of "reasonable expectations", including taking account of thirdparty public statements, is part of a notion of conformity that European contract law has adopted from the United Nations Convention on Contracts for the International Sale of Goods (further on - CISG). The legal traditions of the EU Member States featured greatly varying approaches towards the concepts and the classification of different types of breach, of incorrect performance and of defects. In light of these differences, the Consumer Sales Directive and later directives ${ }^{36}$ drew upon a concept that was already familiar to many Member States from the cross-border sale of goods under the CISG: "conformity" and "non-conformity". In this respect, the academic draft for Principles of European Contract Law had already paved the way for the development and the EU legislator introduced rules on performance obligations and guarantees in line with the tendency that had emerged on the basis of the $\mathrm{CISG}^{37}$. However, the legislator did not simply adopt the provisions from the CISG, but developed them further with provisions such as on incorrect installation or the seller's right of regress if the non-conformity was caused by an earlier link in the contractual chain ${ }^{38}$.

These EU directives on sales law were also inspired by the CISG with respect to the legal consequences of non-conforming performance. However, the remedies in the sales law directives are limited to repeat performance (repair or replacement), price reduction or termination; the Member States have been unable to agree on common rules for damages. The European legislator has also adopted the CISG's hierarchy of remedies, though with modifications. As under the CISG, price reduction and termination are secondary to the repair or replacement of the defective good. However, the thresholds for demanding replacement and for termination are not as high as in the CISG - in EU law the consumer may terminate the contract not only for a "fundamental breach" but for every breach that is "not minor". The consumer must first demand repeat performance, for which the seller has a "reasonable period" before the consumer may terminate the contract. European contract law has therefore shaped its law on remedies whereby the period for repeat performance (and not "fundamental breach") plays a central role and the buyer can terminate the contract much more easily when the non-conformity remains ${ }^{39}$.

35 Schulze R., Zoll F. European Contract Law. Ch. 3. P. 83-86.

36 Such as Directive (EU) 2015/2302 of the European Parliament and of the Council of 25 November 2015 on package travel and linked travel arrangements OJ L 326, 11.12.2015, 1, as well as Directive 2019/770 and Directive 2019/771.

37 See e. g.: Schulze R. The New Shape of European Contract Law // Journal of European Consumer and Market Law. 2015. Vol. 4 (4). P. 139; Schwenzer I., Hachem P. The CISG - A Story of Worldwide Success // CISG Part II Conference / ed. by J. Kleinemann. Uppsala: Iustus Förlag, 2009. P. 125.

38 Art. 2 (5), 4 Directive 1999/44/EC; Art. 8, 18 Directive 2019/771.

39 For detail see: Schulze R., Zoll F. European Contract Law. Ch. 5, 6. 


\section{The effects of digitalization}

\subsection{Changes to contract practice}

The aforementioned innovations in European contract law are by no means exhaustive. The European legislator has, in recent years, tackled the challenges posed by digitalization with legislation which features new concepts and approaches. The legislation thus responds to fundamental changes which have also extended to the instruments and methods of contracting, for instance development of artificial intelligence and the increasing use thereof ${ }^{40}$. "Machine-to-machine" contracting does not just involve the use of artificial intelligence to decide on which contracts are to be concluded and with whom but also its use in modifying the terms of the contract in light of market conditions. Artificial intelligence can determine the content of the contract without the need for human intervention and even when the decision was not even initially foreseeable for the operator ("black box effect" ${ }^{41}$ ). The use of artificial intelligence in contract performance and in response to breaches has also resulted in fundamental changes. This is especially noticeable in so-called "self-executing contracts", for instance credit or insurance contracts which can prevent the use of the object purchased using credit or subject to an insurance policy. The same also applies to "autonomous" services such as the payment of compensation for delayed or cancelled flights. However, these new developments appear to result from legal practice and associated case law without receiving attention in EU legislative measures.

\subsection{The EU's legislative response}

\subsubsection{Supply of digital content and digital services}

The European Commission responded to some of these extensive changes with its 2015 "Digital Single Market Strategy", which announced a number of legislative measures $^{42}$. Since 2015, contract law has seen the introduction of such measures thereby signalling the start of a new phase of European legislation ${ }^{43}$. Where innovative responses to digitalization are concerned, it is indeed the Digital Content Directive which takes centre stage. As also applies to the "twin" Sale of Goods Directive, the Digital Content Directive shall also contribute to the faster growth of the Digital Single Market ${ }^{44}$. Through their combination of continuity and innovation these twin Directives outline European contract law in light of the challenges presented by digitalization.

40 See: Lohsse S., Schulze R., Staudenmayer D. Data as Counter-Performance - Contract Law 2.0? An Introduction // Data as Counter-Performance / eds S. Lohsse, R. Schulze, D. Staudenmayer. BadenBaden: Nomos, 2020. P. 9 et seq.

41 See the contributions from G. Spindler and H. Zech in: Liability for Artificial Intelligence and the Internet of Things / eds S. Lohsse, R. Schulze, D. Staudenmayer. Baden-Baden: Nomos, 2019.

42 COM (2015) 192 final: 20.

43 In addition to Directives 2019/770 and 2019/771, other legislation includes Regulation (EU) 2018/302 of the European Parliament and of the Council of 28 February 2018 on addressing unjustified geo-blocking and other forms of discrimination based on customers' nationality, place of residence or place of establishment within the internal market OJ L 60I, 02.03.2018, 1 and Regulation (EU) 2017/1128 of the European Parliament and of the Council of 14 June 2017 on cross-border portability of online content services in the internal market OJ L 168, 30.06.2017, 1. For details on Regulation 2017/1128 see the commentary by N. Rauer and L. Kaase in: EU Digital Law: Article-by-Article Commentary / eds R. Schulze, D. Staudenmayer. Baden-Baden: Nomos, 2020.

44 The following summarizes: Schulze R., Zoll F. European Contract Law. Ch.1. P. 61 et seq. 
Furthermore, the Modernization Directive ${ }^{45}$ modifies several provisions in consumer contract law in order to accommodate modern practices and legal issues, including those brought about by digitalization. In addition, the Platform Regulation ${ }^{46}$ responds to the increasing importance of online intermediaries for internal market trade, notably with provisions concerning contract terms in commercial contracts.

In principle, the Digital Content Directive covers all types of contracts with consumers for the supply of digital content or digital services, irrespective of their traditional categorization as sale, service, hire etc. Accordingly, the Directive covers the millions of contracts concluded for apps on computers or smartphones, for the streaming of films, music, etc. The central elements of the Digital Content Directive concern the trader's performance obligations and the remedies for the consumer. Furthermore, it contains provisions which determine the extent to which the trader is entitled to modify the contract ${ }^{47}$. The Directive also contains provisions concerning the trader's right of regress against an earlier link in the chain of contracts (e. g. supplier, producer), where this party is has caused the nonconformity.

Separate provisions of the Digital Content Directive concern, on the one hand, the trader's obligation to supply the digital content or digital service (obligation to perform) and, on the other hand, the obligation to perform in conformity with the contract ${ }^{48}$. The Directive also regulates the trader's liability for breach of these obligations and the corresponding remedies for the consumer ${ }^{49}$. Here, the Directive distinguishes again between the non-fulfilment of the performance obligation (i. e. non-performance) and the nonfulfilment of the obligation to perform in conformity with the contract (i. e. non-conforming performance).

\subsubsection{Sale of goods}

The scope and content of the Sale of Goods Directive accords greatly with the Digital Content Directive. This new Directive repeals and replaces the Consumer Sales Directive which since 1999 had harmonized consumer guarantees in the EU, and adapts the consumer protection in this area to the changes brought by digitalization. The Sale of Goods Directive covers both "online" as well as "offline" sales. In contrast to the Digital Content Directive, the scope of the Sale of Goods Directive rests on the classification of the contract as a sales contract (including contracts for the supply of goods to be manufactured or produced). However, the Sale of Goods Directive applies to digital content when (i) the digital content or digital service is incorporated in or inter-connected with goods in such a way that the goods would not be able to perform their functions without such content or service and (ii) the content or service is provided with the goods under the sales contract $^{50}$. If these requirements are not fulfilled, the Digital Content Directive will apply. The Sale of Goods Directive thus applies to the sale of a smartphone including the preinstalled applications according to the sales contract (e. g. the operating system), but

45 Directive (EU) 2019/2161 of the European Parliament and of the Council of 27 November 2019 amending Council Directive 93/13/EEC and Directives 98/6/EC, 2005/29/EC and 2011/83/EU of the European Parliament and of the Council as regards the better enforcement and modernisation of Union consumer protection rules OJ L 328, 18.12.2019, 7.

46 Regulation (EU) 2019/1150 of the European Parliament and of the Council of 20 June 2019 on promoting fairness and transparency for business users of online intermediation services OJ L 186, 11.07.2019, 57.

47 Art. 19 Directive 2019/770.

48 Arts 5 and 6 Directive 2019/770.

49 Art. 11 et seq. Directive 2019/770.

50 In cases of doubt this is to be presumed according to Art. 3 (4) Directive 2019/770 and Art. 3 (3) Directive 2019/771. 
the Digital Content Directive will apply to any applications subsequently downloaded and installed on the smartphone (e. g. a game $)^{51}$.

The provisions on conformity and the consumer's remedies mainly follow the approach under the Consumer Sales Directive. However, there are distinctions in some core areas (e. g. the new notion of "durability" as an objective requirement for conformity, and the one year period for the reversal of the burden of proof $)^{52}$. In particular, the Sale of Goods Directive extends beyond the Consumer Sales Directive by aligning with Digital Content Directive by taking account of new developments in contract practice brought about by digitalization. This applies especially to the requirements for conformity (such as "functionality", "compatibility" and "interoperability"; the update obligation, and integration of digital content into the digital environment). Together with the Digital Content Directive, the Sale of Goods Directive thus contributes to the creation of a consumer contract law for the digital age.

\subsubsection{Modernization Directive}

The European legislator took a further step in the same direction with the 2019 Modernization Directive, which modifies and adds to a number of existing directives - for instance by adapting the terminology and content - in order to improve enforcement and to modernize EU consumer protection rules ${ }^{53}$. This includes the role of online intermediaries or "online marketplaces" and ranking in modern commercial practice ${ }^{54}$, aligning various definitions under the Consumer Rights Directive, changing the earlier provisions on the scope and the obligations of the trader ${ }^{55}$, and extending the application of pre-contractual information obligations to online marketplaces ${ }^{56}$.

\subsubsection{Online intermediaries}

The further development of European contract law as a result of digitalization is not limited to consumer law. Commercial contracts, i. e. B2B contracts, have also been subject to the developments, more specifically through the Platform Regulation ${ }^{57}$. This Regulation concerns, for instance, online intermediation services, online search engines as well as online software application services and online social media services. Its main aim is to increase the transparency of contract terms and business models in the use of such of such online intermediaries by businesses. For instance, it provides that terms and conditions should not only be drafted in plain and intelligible language and be easily accessible but they should also contain specific information ${ }^{58}$. Whereas the 1993 Unfair Terms Directive only covers the control of terms in consumer contracts, the Platform Regulation now ventures into the control of contract terms in commercial contracts.

51 For these and further examples see recitals 21 and 22 Directive 2019/770.

52 For detail see: Schulze R., Zoll F. European Contract Law. Ch. 5. P. 45 et seq., and Ch. 6. P. 33 et seq.

53 On the proposal see: Twigg-Flesner C. Bad Hand? The "New Deal" for EU Consumers // European Union Private Law Review (GPR). 2018. Vol. 15. P. 166.

54 Inter alia through changes to Directive 2011/83/EU and Directive 2005/29/EC of the European Parliament and of the Council of 11 May 2005 concerning unfair business-to-consumer commercial practices in the internal market OJ L 149, 11.06.2005, 22.

55 For example, Art. 3 (1) and (1a), Art. 5 (1) (e) and (g), Art. 6 (1) (r) and (g) Directive 2011/83/EU following the changes by Art. 4 Directive 2019/2161.

56 See Art. 6a Directive 2011/83/EU introduced by Art. 4 Directive 2019/2161.

57 For an overview see: Höppner T., Schulz A. Die EU-Verordnung 2019/1150 für Fairness und Transparenz von Online-Vermittlungsdiensten ("P2B-Verordnung") // ZIP: Zeitschrift für Wirtschaftsrecht. 2019. Bd. 40 (49). S. 2329.

58 Art. 3 Regulation 2019/1150. See also: Von Westphalen F. G. B2b-Plattform-Verordnung: Das AGB-Recht vor weitreichenden Veränderungen // Betriebs-Berater. 2020. Nr. 11. S. 579. 
European contract law therefore takes into account the fact that the widespread use of standardized contracts (including in commercial contracts) in almost all business sectors increasingly contradicts the practice of contracting and the traditional focus of contract law on individually-negotiated contracts ${ }^{59}$. A particular characteristic of modern manufacturing processes since the Industrial Revolution, namely mass production, has been expressed in contract practice in the mass use of standardized contract terms by one or both contracting parties. In the modern economy, this standardization not only continues at the various levels of the distribution of goods but also extends to the broad sector of services, with its equally diverse variety of contract types and rules. Digitalization, however, has taken the use of standardized contracts to a new level: standardization has become typical when concluding contracts on the Internet, whereas individual negotiation as both a process and a reflection of the content is the exception. Moreover, in the course of digitization, the conventional electronic conclusion of contracts, in which at least one natural person is usually directly involved, is largely replaced by "machine-tomachine contracts". This has the consequence that the standardized contract terms can also be further developed by "artificial intelligence" without the direct involvement or even knowledge of a natural person in accordance with the changed market conditions. In addition, standardization in many contracts, in particular in the supply of digital content, covers not only the conclusion of the contract but also other phases of its execution and the instruments for amending and terminating the contract. These new forms of standardized contracts will continue to occupy the European legislator in the coming years. With the inclusion of the control of contract terms in the Platform Regulation, an important step has been taken to avoid narrowing the scope to consumer law and also to take into account the importance of standardized commercial contracts.

Beyond this fundamental decision to extend the control of contract terms to commercial contracts, two aspects of the transparency requirement under the Platform Regulation are particularly innovative: the obligation to give reasons if the provision of the online intermediation service is restricted, suspended or terminated and the obligation to set out and give reasons for the main parameters determining ranking of search engine results ${ }^{60}$. A similar obligation also exists for any differentiated treatment given by the online intermediary service or online search engine in relation to goods or services ${ }^{61}$. Furthermore, the intermediary service (with the exception of smaller intermediaries is are obliged to provide for an internal system for handling the complaints of commercial users and to identify mediators ${ }^{62}$. Moreover, particular organizations or associations and public bodies have the right to take action before the competent courts for breaches of the Regulation ${ }^{63}$. However, the Regulation does not include provisions concerning the liability of the online intermediary as the (often dominating) third party in the contractual relationship and at the conclusion of contract between the commercial users and their customers ${ }^{64}$. It remains to be seen how this question will be tackled in the forthcoming "Digital Services Act"65.

59 For the following in more detail and with further evidence: Schulze R., Arroyo Vendrell T. Standardized Contracts between Private Autonomy and Legal Control - An Introduction // Standardisierte Verträge - zwischen Privatautonomie und rechtlicher Kontrolle / Hrsg. T. A. Vendrell, J. Kindl, M. P. Perales Viscasillas. Baden-Baden: Nomos, 2017. S. 11 et seq.

60 Arts 4 and 5 Regulation 2019/1150.

61 Art. 7 Regulation 2019/1150.

62 Arts 11 and 12 Regulation 2019/1150.

63 Art. 14 Regulation 2019/1150.

64 For a more extensive regulation see: Model Rules on Online Platforms. European Law Institute, 2019. - See also: Schulte-Nölke H. Plattformverträge und Vertrauensschutz // Vertrauensschutz im digitalen Zeitalter / Hrsg. U. Blaurock, F. Maultzsch. Baden-Baden: Nomos, 2020. S. 167.

65 For details see: https://www.europarl.europa.eu/legislative-train/theme-a-europe-fit-for-thedigital-age/file-digital-services-act (accessed: 14.10.2020). 


\section{The new legal landscape}

\subsection{Data: Definition}

The role of data in contractual relationships is a consistent theme within this recent EU legislation which has brought about many changes to the legal landscape in contract law $^{66}$. For example, the concept of data serves to define the supply of "digital content" under the Digital Content Directive and to determine the scope of the Sale of Goods Directive. Digital content is "data produced and supplied in digital form" 67 . The Modernization Directive adopts these concepts for other provisions of consumer protection law.

Although broad rules on the supply of digital content are lacking for commercial contracts $^{68}$, provisions on data in such contracts feature in recent EU legislation and play a significant role. To give but one example: the access to data is a key feature of the Platform Regulation with regard to contracts between online intermediaries and commercial users $^{69}$. In these provisions of European contract law, as well as in others, one can see the economic importance of data and its nature as an asset in the "digital economy"70.

\subsection{Data as counter-performance}

The Digital Content Directive clearly shows that data is of considerable importance not just for performance obligations in modern contract law but also for the counter-performance that is to be provided in return for the supply of digital content or digital services $^{71}$. The Directive ensures that the consumer is protected irrespective whether the counter-performance is the payment of a price or the supply of personal data ${ }^{72}$. In modern contract practice, the supplier of digital content or digital services may require the counterparty to provide data in return ${ }^{73}$. For instance, consumers often have to provide their (personal) data (age, location, profession, shopping habits) to suppliers of online services (e. g. messaging services, social media etc.). Although consumers often believe that they are receiving such services without charge, the data they provide may have considerable economic value and thus be comparable to money. Whereas the supplier may receive the economic benefits from the data in, for example, customer loyalty schemes or (personalized) advertising, it can also profit from the sale of the data to companies who collect and process the data they sell it on to advertising agencies. The Digital Content Directive reflects the economic significance of data by including the supply of personal data alongside the payment of a price.

66 For further details see: Schulze R., Zoll F. European Contract Law. Ch. 2. P. 80 et seq., Ch. 3. P. 78 et seq., and Ch. 5. P. 34 et seq.

67 Art. 2 No. 1 Directive 2019/770; Art. 2 No. 6 Directive 2019/771. The definition of data also plays a role in defining "digital services" in Art. 2 No. 2 Directive 2019/770 and Art. 2 No. 7 Directive 2019/771.

68 See: Schulze R., Zoll F. European Contract Law. Ch. 1. P. 79; Statement of the European Law Institute on the European Commission's. Proposed Directive in the Supply of Digital Content to Consumers. European Law Institute, 2016. https://www.europeanlawinstitute.eu/fileadmin/user_upload/p_eli/Publications/ELI_Statement_on_DCD.pdf (accessed: 14.10.2020).

69 Art. 5 Regulation 2019/1150. See: Trading Data in the Digital Economy / eds S. Lohsse, R. Schulze, D. Staudenmayer. Baden-Baden: Nomos, 2017.

70 Furthermore, the role played by data gives rise to a multitude of questions surrounding data protection, rights to data and access to data, however these cannot be explored in detail here, see: Lohsse S., Schulze R., Staudenmayer D. Data as Counter-Performance - Contract Law 2.0? P. 9 et seq.

71 See: Ibid.

72 Art. 3 (1) Directive 2019/770, likewise Art. 3 (1a) Directive 2011/83/EU.

73 On the difficulties in qualifying personal data as counter-performance see: Schulze R., Zoll F. European Contract Law. Ch. 2. P. 76 et seq. 
In this respect, the provision of data has equal status as the payment of a price, however it does not mean that the rights to personal data are equal to property (or quasiproperty) rights. In contrast to the transfer of property, the transfer of data often does not result in a loss to the transferring party. In principle, data can be reproduced without any loss in value ${ }^{74}$. The approach in the new legislation recognizes, however, that the provision of data (like the payment of a price) is the transfer of something of value and the trader (as the recipient of this counter-performance) is as such generally subject to the same obligations under the Directives as would arise if the consumer were to pay a price as counterperformance. Accordingly, the rights under the Directives are available to the consumer who provides personal data as counter-performance ${ }^{75}$.

Although the provisions on the payment of a price and the supply of personal data merely determine the Directive's scope of application, the provisions themselves express a perspective that can be of considerable importance for EU and national law ${ }^{76}$. This primarily concerns the nature of the contract as synallagmatic and therefore the question of how the provisions of national law for such contracts apply. The Directives may be relevant with respect to the questions whether and under which conditions a contract is concluded when a customer does not pay a monetary price, but provides her personal data instead. The conclusion of contract and the validity of contracts still remain in the domain of national law ${ }^{77}$, but these provisions of EU law could impact on how national law is understood. For instance, in principle "consideration" is necessary under the common law in order to conclude a valid contract, and therefore the question arises whether personal data satisfies the common law requirements for valid consideration ${ }^{78}$. The role attributed to data may be relevant also in civil law jurisdictions in determining whether a party intends to be bound by a contract. Indications of or criteria for the intention to be legally bound may therefore also rest on the treatment of personal data as counter-performance as under the Digital Content Directive ${ }^{79}$, which is to be transposed into national law.

\section{Contractual obligations}

\subsection{General developments}

Where the parties' contractual obligations are concerned, recent EU legislation has developed innovative approaches in response to the challenges created by digitalization. However, beyond this the legislation has also introduced various more general innovations, three of which will be discussed here ${ }^{80}$.

${ }^{74}$ For details see: Trading Data in the Digital Economy / eds S. Lohsse, R. Schulze, D. Staudenmayer. Baden-Baden: Nomos, 2017.

75 See: Schulze R., Zoll F. European Contract Law. Ch. 5. P. 34 et seq. - See also D. Staudenmayer on Art. 3 Digital Content Directive: EU Digital Law: Article-by-Article Commentary / eds R. Schulze, D. Staudenmayer. P. 46 et seq.

76 See: Lohsse S., Schulze R., Staudenmayer D. Data as Counter-Performance - Contract Law 2.0? P. 9 et seq.

77 Art. 3 (10) Directive 2019/770; Art. 3 (5) Directive 2011/83/EU. See Recital 12 Directive 2019/770.

78 See: Drahaman C. M. A collision of contract and privacy law in a digital environment // The Future of the Law of Contract / ed. by M. Furmston. Abingdon: Routledge, 2020. P. 151 et seq.

79 Art. 3 (1) Directive 2019/770.

80 Further new aspects of considerable importance for contract practice include, inter alia, the relationship between "subjective" and "objective" requirements for conformity. In comparison to earlier legislation, the new Directives have strengthened the role of the latter (which determine the obligations for the trader irrespective of the agreement between the parties) and thus increased the level of consumer protection. See: Schulze R., Zoll F. European Contract Law. Ch. 5. P. 37 et seq. 


\subsubsection{Towards general contract law}

The Digital Content Directive transfers concepts such as conformity and non-conformity from their current home in (consumer) sales law to a more general level which, in principle, covers a broad spectrum of traditional types of contract. The Directive applies not only to sales contracts but also to all types of contracts which concern the supply of digital content or digital services - from quasi sales contract (such as the purchase of a video file) to (digital) service contracts (such as online storage in a "cloud") to contracts resembling hire contracts (such as the rental of a video file for a period of time). The Directive also releases several other concepts previously specific to sales law and gives them overarching relevance (e. g. the remedies for the consumer and the supplier's right of regress). The sales law concerning consumer guarantees has given rise to a number of general concepts that apply to all types of contracts for digital content and digital services and which may gain in significance in the future.

\subsubsection{Notion of performance}

The Digital Content Directive also includes both sides to contractual performance obligations: on the one hand, the obligation for the supplier to supply the digital content or digital service, on the other hand, the obligation to supply the digital content or digital service in conformity with the contract (i. e. without defects). For various traditional types of contracts, a single piece of EU legislation now unifies the performance obligations "performance" and "performance in conformity with the contract". Accordingly, the Digital Content Directive also constitutes a set of rules which contains provisions both on the liability for the failure to perform at all (non-performance) and the failure to perform in conformity (non-conforming performance).

\subsubsection{Durability}

Under the new Sale of Goods Directive, and in contrast to the Consumer Sales Directive, "durability" is now an element of conformity and thus sales law features a response to environmental protection concerns. The Sale of Goods Directive may not have followed further proposals to introduce sustainability into contract law ${ }^{81}$, but it has at least opened the door to future developments and, in light of the considerable importance the European Commission has attached to environmental protection and climate change, one can expect future contract law legislation to contain further steps in this direction.

\subsection{Update obligation}

The new provisions on "updates" deserve particular attention as they illustrate how digitalization has impacted on the performance of contractual obligations. Whereas traditionally in sales contracts the time of delivery is decisive for determining conformity with the contract (or the absence of defects) ${ }^{82}$, the conformity in the supply of digital content or a digital service and the corresponding liability of the trader extends over a period of time ${ }^{83}$. If the contract provides for single supply (e. g. the single download of a speech recognition software or a translation program), this period is not generally fixed in months or years, but depends on reasonable consumer expectations according to the specific

81 For criticism see: Kieninger E. -M. Recht auf Reparatur ("Right to Repair") und Europäisches Vertragsrecht // Zeitschrift für europäisches Privatrecht. 2020. Bd. 2. S. 274 et seq.

82 Art. 10 (1) Directive 2019/771.

83 Art. 8 (1), 11 (2) and (3) Directive 2019/770; Art. 10 (2) Directive 2019/771. 
circumstances and the nature of the contract. In the case of a contract for continuous supply over a period of time (e. g. a streaming subscription), the trader is to supply updates for the period during which the digital content or digital service is to be supplied under the contract. If during this period the seller or supplier does not fulfil his obligation to provide the necessary updates, including security updates, the consumer shall be entitled to the remedies provided for a lack of conformity.

This update obligation is combined with two other notable approaches in the new European directives. On the one hand, the distinction between a single act of supply (i. e. one-off performance) and performance over a period of time has formed a new structural feature of European contract law with regard to digital products. Beyond the aforementioned provisions on conformity, this distinction also provides the basis for the differences with regard to liability for lack of conformity, the burden of proof and the right to terminate the contract ${ }^{84}$. On the other hand, the Digital Content Directive and the Sale of Goods Directive introduce - in parallel to the obligation to update - the obligation for the trader to inform the consumer about the necessary updates ${ }^{85}$. While previous directives in European consumer law primarily laid down pre-contractual information obligations, the new legislation thus also addresses the existence of possible information asymmetries between the parties in the performance of the contract.

In addition, the provisions on the right of modification under the Digital Content Directive are closely related to the update obligation ${ }^{86}$. This provision allows the trader to change digital content or services that he has to provide during a period of time beyond the "updates" due to the update obligation. As a result of this potential to make changes, the trader can, for example, provide the consumer with a new version of the digital content to keep abreast of the new technological developments. Under the Directive, however, it is not sufficient that the contract provides for the right to make such modifications (as might be assumed on the basis of the principle of freedom of contract). Rather, the Directive contains further requirements ${ }^{87}$ and thus, in the interest of consumer protection, sets narrow limits on the power to make changes ${ }^{88}$. In addition, the Digital Content Directive grants the consumer a right to terminate the contract if the modification negatively impacts the consumer's access to or use of the digital content or digital service, unless such negative impact is only minor. The Directive therefore seeks to balance the interests of the consumer and the trader with regard to the modification of the performance obligations by recognizing the trader's right to make modifications, but at the same time limiting this right and granting the consumer the possibility to terminate the contract.

On the whole, these provisions set out some of the cornerstones of modern contract law in the "age of digitization". The update obligation over a reasonable period of time is of fundamental importance for the use of digital products. Determining this period specifically in each case requires a distinction between one-time provision and continuous supply over a period of time. In order to ensure that the consumer (or other customer) is able to request and carry out the update, there is the need to correlate the update obligation with information obligations. In addition, in cases where updating becomes too demanding due to technological developments, it is necessary to guarantee and at the same time

84 Art. 11 (2) and (3), Art. 12 (2) and (3), Art. 16 (1) Directive 2019/770.

85 Art. 8 (2) Directive 2019/770; Art. 7 (3) Directive 2019/771.

${ }^{86}$ Art. 19 Directive 2019/770.

87 For details see M. Wendland on Art. 19 Digital Content Directive in: EU Digital Law: Article-by-Article Commentary / eds R. Schulze, D. Staudenmayer. P. 319-321.

${ }^{88}$ According to Art. 19 Directive 2019/770, the modification is only permissible if the contract allows, and provides a valid reason for, such a modification and such a modification is made without additional cost to the consumer. The consumer must also be informed in a clear and comprehensible manner of the modification. 
limit the right to modify the content of the contract in favour of supplying a new version of the digital content. In so doing one can balance the interests of the parties. In the future, this model in the new European directives could potentially serve as a basis for provisions that go beyond consumer law in order to develop the responses in private law to the challenges of digitization.

\subsection{Digital environment}

The new directives provide a further underlying feature of contract law in the "digital age" by taking into account the relationship between the digital content owed and the consumer's digital environment ${ }^{89}$. This concerns situations in which the software is not compatible with the consumer's hardware (e. g. due to the graphic card) or the software cannot function with software present in the consumer's computer (e. g. due to the operating system). In such cases, the interaction of the provided digital content with the digital environment cannot be attributed solely to the consumer's sphere of influence. The obligation of the supplier to perform in conformity with the contract may rather also extend to consideration of the consumer's digital environment. The Directives specify this on several levels. In the case of the "objective" requirements for contractual conformity, this is achieved above all through the criteria of functionality and compatibility; for the "subjective" requirements, through the additional criterion of interoperability. A further provision supplements the "objective" criteria with regard to specific aspects of improper integration into the digital environment. According to the Digital Content Directive, any lack of conformity resulting from the incorrect integration of the digital content or digital service into the consumer's digital environment shall be regarded as lack of conformity of the digital content or digital service if integrated by the trader or under the trader's responsibility; or the digital content or digital service was intended to be integrated by the consumer and the incorrect integration was due to shortcomings in the integration instructions provided by the trader ${ }^{90}$. This provision ties in with an innovation from the first phase in the development of European contract law: the seller's liability for incorrect installation and for shortcomings in the instructions (e. g. if a furniture store provides the consumer with incorrect assembly instructions). The new legislator develops this approach from sales law in order to take account of the interdependence of these digital products with their environment. Given the constant interplay of many digital products in almost all economic activities, consideration of this interdependence should also extend beyond consumer law to become one of the hallmarks of modern contract law.

\section{Remedies and unwinding contracts}

\subsection{Overview}

The Directives' provisions on consumer's remedies for non-conformity and the approach to unwinding terminated contracts are largely anchored in concepts familiar to the consumer sales law still in force. This applies above all to the structure of remedies, including the fundamental priority of repeat performance over termination and price reduction. However, the Digital Content Directive in particular goes far beyond the present EU law concerning termination and develops notable new approaches. In contrast to the Consumer Sales Directive, the Digital Content Directive does not merely determine the

89 For the following see: Schulze R. Die Digitale-Inhalte-Richtlinie // Zeitschrift für europäisches Privatrecht. 2019. Bd. 4. S. 712-713; Schulze R., Zoll F. European Contract Law. Ch. 5. P. 52-53.

90 Art. 9 Directive 2019/770; see also Art. 8 Directive 2019/771.

Правоведение. 2020. Т. 64, № 2 
obligations of the trader but also regulates the mutual obligations after the termination of contract. Moreover, the application of this regime does not only relate to the termination of the contract due to a lack of conformity (as under the Consumer Sales Directive) but covers two further situations: the termination of the contract due to the failure to perform (non-performance) and the termination of the contract by the consumer due to a modification by the trader ${ }^{91}$.

This set of rules on the termination of contract contains three approaches that are of potential relevance for modern contract law beyond consumer protection: the prohibitions on the use of data; data retrieval; and the special features of the provision of digital content over a period of time ${ }^{92}$.

\subsection{Prohibition on use}

The traditional model in which a good is returned to the seller upon termination of the contract cannot apply to digital products due to their intangible nature. It is therefore necessary for the recipient to refrain from using the digital product. The Digital Content Directive provides in this regard that the consumer is to refrain not only from using the digital content or digital service after termination of the contract but also from making it available to third parties ${ }^{93}$. For example, a consumer may no longer use speech recognition software or make it available for use by a third party if she has terminated the contract. Although the provision, according to its wording, contains an obligation to "cease and desist", the consumer may also be obliged to take active steps to effectively exclude use by a third party (e. g. by deleting the digital content and any usable copy).

However, it is clear that compliance with is difficult to verify and enforce by the other party. The Digital Content Directive aims to solve this problem, at least partially, by granting this other party the right to prevent any further use, in particular by making the digital content or digital service inaccessible to the consumer or disabling her user account (for example by a pre-determined blocking mechanism) ${ }^{94}$.

Prohibition of use may not only be used against the consumer, but can also be used by the consumer against the trader. If the consumer, in using the digital content provided, has in turn provided the trader with digital content (such as images, video files or files created on mobile devices ${ }^{95}$, the trader may no longer use this content after termination of the contract ${ }^{96}$. With regard to personal data, the Digital Content Directive refers to the General Data Protection Regulation ${ }^{97,98}$, which is to regulate this matter entirely and which generally takes priority over the Digital Content Directive in the event of conflicts $^{99}$. The Digital Content Directive provides for exceptions to this prohibition of use in order to avoid unnecessary expense for both parties and to take account of the principle of proportionality ${ }^{100}$.

91 Art. 19 (3) Directive 2019/770.

92 For details see C. Twigg-Flesner on Art. 16 Digital Content Directive in: EU Digital Law: Article-byArticle Commentary / eds R. Schulze, D. Staudenmayer. P. 281-296.

93 Art. 17 Directive 2019/770.

94 Art. 16 (5) Directive 2019/770.

95 See Recital 69 Directive 2019/770.

96 Art. 16 (3) Directive 2019/770; however, this only applies to the consumer's non-personal data.

97 Regulation (EU) 2016/679 of the European Parliament and of the Council of 27 April 2016 on the protection of natural persons with regard to the processing of personal data and on the free movement of such data OJ L 119, 04.05.2016, 1.

98 Art. 16 (2) Directive 2019/770.

99 Art. 3 (8) Directive 2019/770.

100 Art. 16 (2) Directive 2019/770. For details see C. Twigg-Flesner on Art. 16 Digital Content Directive in: EU Digital Law: Article-by-Article Commentary / eds R. Schulze, D. Staudenmayer. P. 24 et seq. 


\subsection{Data retrieval}

In addition to the prohibition of use, the Digital Content Directive obliges the trader to make available to the consumer, upon request, the (non-personal) data the consumer has provided or created in using the digital content or digital service ${ }^{101}$. If, for example, text files have been stored on the trader's server when using a translation software, the trader must make this data available to the consumer. For this purpose, the trader must grant the consumer access to the server or provide the consumer with a copy of the file. In order to ensure the effectiveness of the right to recover data, the Directive provides details concerning the recovery ${ }^{102}$.

\subsection{Reimbursement in contracts for continuous supply}

As regards the price paid by the consumer for the provision of digital content or digital services, the same principle applies as for the sale of goods: the trader is obliged to refund the price paid. However, this obligation to refund is subject to particular requirements if the performance is to be provided for a certain period of time (such as streaming) and is not in conformity with the contract for only part of that period. In this case, similar considerations apply as in the case of price reduction. According to the Digital Content Directive, the trader shall reimburse the consumer only for the proportionate part of the price paid corresponding to the period of time during which the digital content or digital service was not in conformity ${ }^{103}$. The consumer is therefore only liable to pay for the use of the digital content or services during the period in which it was in conformity. If, at the time of termination, the trader has already received advance payment, he must refund that part of the total price paid by the consumer in advance for any period of the contract that would have remained had the contract not been terminated.

\subsection{Fundamental features of unwinding terminated contracts}

In viewing the provisions contained in the new directives, and in particular those of the Digital Content Directive on the termination of contract, one can see a number of fundamental features for the modern design of this subject matter, taking into account the changes brought about by digitization. These fundamental features can supplement traditional principles in European contract law such as the obligation to return physical objects received by one party from the other under the contract; the free return of goods in consumer contracts, and the obligation to refund the price paid. For contracts on the supply of digital content over a period of time, this latter principle is supplemented by the rule on pro rata reimbursement of the price. However, the new provisions also provide models for other aspects of the termination of contracts for the supply of digital content which may be relevant beyond consumer law. This applies in particular to the prohibition of using digital content and digital services from using data for their own purposes and making it available to third parties, and the authorization for the trader to block the use. In view of the extensive digitization in almost all social and economic sectors, the right to retrieve data is no less relevant for the termination of failed contracts if a recipient of digital content has made this data available to the other party to the contract when using it. These fundamental aspects of the provisions on termination under the Digital Content Directive could

101 Art. 16 (4) Directive 2019/770.

102 In particular, the consumer shall be entitled to retrieve that digital content free of charge, without hindrance from the trader, within a reasonable time and in a commonly used and machine-readable format. ${ }^{103}$ Art. 17 (3) Directive 2019/770. 
therefore offer suggestions both for the EU and for individual Member States to include this matter in a modern general contract law.

\section{Conclusions}

The most recent EU legislation thus offers a wide range of suggestions on how modern contract law can be designed to meet the challenges of digitization. Despite serious shortcomings, which are mainly due to the fragmented regulatory approach, this legislation and the legal doctrine related to it have produced a number of innovative approaches in various fields from the conclusion of the contract to the termination thereof.

Such innovative approaches were characteristic of EU contract law already in the first phase of its development. This included, for example, the development of legal instruments to guide market behaviour with objectives such as the strengthening of the internal market and consumer protection (inter alia, by compensating for asymmetries between the parties when concluding a contract by means of instruments such as pre-contractual information obligations and rights of withdrawal). In addition, the EU legal acts embedded the development of European contract law in the context of international trends by adopting core concepts of the CISG (such as conformity and lack of conformity) - first for consumer sales contracts and now also for other types of contracts. The European legislation certainly set its own accents. In particular, it dispensed with the concept of "fundamental breach of contract" from the CISG. Instead, it extended the meaning of the additional period for performance, before the creditor is entitled to switch from her demand for subsequent performance to the legal remedies of termination and price reduction. Many of these new approaches influenced the law of the EU Member States not only within the scope of the relevant European directives, but also provided impulses for more far-reaching reforms of national contract law (for example, the modernization of the law of obligations in Germany in 2002 and the reform of contract law in France in 2016).

Beyond such new approaches from the first phase of the development of European contract law, European legislation has responded in recent years with further innovations to the changes that are taking place in contracting practice of as a result of digitization. Consumer protection in the supply of digital content and digital services has taken on a pioneering role. Within its framework, a number of legal principles and concepts considered in greater detail above have been introduced, but in future these will also deserve attention beyond the legal relationships between consumers and businesses.

This applies in particular to the update obligation. It is a legal consequence of the rapid technological change of digital products and therefore forms a significant part of the adaptation of contract law to the changes brought about by digitization. This also applies to the accompanying introduction of information obligations relating to the need for updates and to the distinction between "one-off" performance and performance over a period of time with regard to the duration of the update obligations. No less significant for the further development of contract law in the light of digitization are the provisions that take into account the interdependence between the subject matter of the contract and its digital environment. This interdependence is one of the characteristics of digitization determined by technology. It is reflected in the new legislation, inter alia, in the provisions on conformity in criteria such as functionality, interoperability and compatibility and through specific provisions on the integration of digital content and digital services into the consumer's digital environment.

However, the most recent further development of European contract law already extends to the commercial field for some matters. This includes not only the extension of the regress of the final seller, which previously concerned the sale of goods and is now applicable to all types of contracts for the supply of digital contents and digital services. 
Even more significant is the introduction of control of contract terms in contracts between online intermediaries with commercial users, both because of its direct effect in this core area of the digital economy and because of its signalling effect in the long-running dispute as to whether the control of terms in commercial contracts is appropriate at all. In addition, this further development is combined with two new forms of the transparency principle: the obligation to provide reasons for restrictions to the detriment of individual platform users; and the disclosure obligation regarding the parameters for the ranking of users both of fundamental importance for balancing the interests of the contracting parties in this area in light of the frequently dominant position of the platforms.

EU contract law, as a relatively new "law in progress", can sometimes respond to such new challenges more quickly and appropriately than many national laws, which are more closely integrated into the body of a long-established terminology and system. Nevertheless, it is clear that EU legislation has not yet provided adequate answers to all the challenges posed by the technological and economic changes brought about by digitization. For example, the regulations on online intermediaries are primarily aimed at transparency for commercial users, while comparable protection and, in particular, liability provisions for the benefit of consumers are expected but are nonetheless still missing. The legal issues of concurrence of intention, lack of intention and agency when concluding "machine-to-machine" contracts have also not yet found an answer at European level, nor have the problems that arise with "self executing contracts" with "autonomous" sanction mechanisms for consumer protection. Likewise, to give just one more example, there are still no rules on compensation for damages in the supply of digital content and services, with the result that consumers and traders are still uncertain about the risks involved in cross-border contracts. Alongside all of these challenges, however, it will be a further task for modern contract law to address environmental concerns. The introduction of "durability" as a requirement for conformity is, in light of the importance of environmental protection in the EU, probably just a first step in this direction.

These new approaches in European legislation clearly show that the further development of contract law is facing challenges that go beyond this area of law. The modernization of contract law therefore raises questions that must ultimately be directed at clarifying the overarching features of European private law as a whole. For example, the interaction of contract law and licensing law in the distribution of digital products needs to be clarified. The same applies to the structuring of contractual liability and the various types of noncontractual liability (in particular product liability and liability of the operator), especially in the production and use of "artificial intelligence". In addition, the role of insurance contract law must also be considered in this context. Finally, the relationship between the law of obligations on the one hand and property law or intellectual property law on the other, and possibly a new definition of the boundaries and interaction between these areas, can be considered if contract law recognizes data as an asset, but without being able to guarantee sufficient protection of these assets with its instruments alone. Embedding the new concepts, principles and rules in the field of contract law in a development of private law as a whole, in line with the changes in the "digital age", will therefore remain a major task for legislation and legal doctrine in the EU and beyond.

\section{References}

Drahaman, Cirami Mastura. 2020. A collision of contract and privacy law in a digital environment. The Future of the Law of Contract, ed. by Michael Furmston: 141-159. Abingdon, Routledge.

Eidenmueller, Horst, Faust, Florian, Grigoleit, Hans Christoph, Jansen, Nils, Wagner, Gerhard, Zimmermann, Reinhard. 2008. Der Gemeinsame Referenzrahmen für das Europäische Privatrecht. JuristenZeitung 63 (11): 529-550. 
Hallstein, Walter. 1964. Angleichung des Privat- und Prozessrechts in der Europäischen Wirtschaftsgemeinschaft. Rabels Zeitschrift für ausländisches und internationales Privatrecht 28 (2): 211-231.

Honsell, Heinrich. 2008. Die Erosion des Privatrechts durch das Europarecht. ZIP: Zeitschrift für Wirtschaftsrecht 29 (14): 621-630.

Höppner, Thomas, Schulz, André. 2019. Die EU-Verordnung 2019/1150 für Fairness und Transparenz von Online-Vermittlungsdiensten ("P2B-Verordnung"). ZIP: Zeitschrift für Wirtschaftsrecht 40 (49): 2329-2337.

Janssen, André. 2017. Präventive Gewinnabschöpfung. Tübingen, Mohr Siebeck.

Kieninger, Eva-Maria. 2020. Recht auf Reparatur ("Right to Repair") und Europäisches Vertragsrecht. Zeitschrift für europäisches Privatrecht 2: 264-279.

Kötz, Hein. 2015. Europäisches Vertragsrecht. Tübingen, Mohr Siebeck.

Lando, Ole, Beale, Hugh (eds). 1999. Principles of European Contract Law. Alphen aan den Rijn, Kluwer.

Lohsse, Sebastian, Schulze, Reiner, Staudenmayer, Dirk (eds). 2017. Trading Data in the Digital Economy. Baden-Baden, Nomos.

Lohsse, Sebastian, Schulze, Reiner, Staudenmayer, Dirk (eds). 2019. Liability for Artificial Intelligence and the Internet of Things. Baden-Baden, Nomos.

Lohsse, Sebastian, Schulze, Reiner, Staudenmayer, Dirk. 2020. Data as Counter-Performance Contract Law 2.0? An Introduction. Data as Counter-Performance, eds Sebastian Lohsse, Reiner Schulze, Dirk Staudenmayer: 9-22. Baden-Baden, Nomos.

Pfeiffer, Thomas, Wais, Hannes. 2021. Judicial Review of Commercial Contracts. Munich, C. H. Beck. (Forthcoming)

Pfeiffer, Thomas. 2007. New Mechanisms for Concluding Contracts. New Features in Contract Law, ed. by Reiner Schulze: 161-168. Munich, Sellier.

Schulte-Nölke, Hans. 2020. Plattformverträge und Vertrauensschutz. Vertrauensschutz im digitalen Zeitalter, Hrsg. Uwe Blaurock, Felix Maultzsch: 167-220. Baden-Baden, Nomos.

Schulze, Reiner, Arroyo Vendrell, Tatiana. 2017. Standardized Contracts between Private Autonomy and Legal Control - An Introduction. Standardisierte Verträge - zwischen Privatautonomie und rechtlicher Kontrolle, Hrsg. Tatiana Arroyo Vendrell, Johann Kindl, Maria Pilar Perales Viscasillas: 11-26. Baden-Baden, Nomos.

Schulze, Reiner, Staudenmayer, Dirk (eds). 2020. EU Digital Law: Article-by-Article Commentary. Baden-Baden, Nomos.

Schulze, Reiner, Zoll, Fryderyk. 2021. European Contract Law. Fully revised $3^{\text {rd }}$ ed. Baden-Baden, Nomos.

Schulze, Reiner. 2005. European Private Law and Existing EC Law. European Review of Private Law 13 (1): 4-20.

Schulze, Reiner. 2007. The New Challenges in Contract Law. New Features in Contract Law, ed. by Reiner Schulze: 3-24. Munich, Sellier.

Schulze, Reiner. 2015. The New Shape of European Contract Law. Journal of European Consumer and Market Law 4 (4): 139-144.

Schulze, Reiner. 2019. Die Digitale-Inhalte-Richtlinie. Zeitschrift für europäisches Privatrecht 4: 695-723.

Schwenzer, Ingeborg, Hachem, Pascal. 2009. The CISG - A Story of Worldwide Success. CISG Part II Conference, ed. by Jan Kleinemann: 119-140. Uppsala, lustus Förlag.

Twigg-Flesner, Christian. 2010. Introduction. The Cambridge Companion to European Union Private Law, ed. by Christian Twigg-Flesner: 1-19. Cambridge, Cambridge University Press.

Twigg-Flesner, Christian. 2018. Bad Hand? The "New Deal" for EU Consumers. European Union Private Law Review (GPR) 15: 166-175.

Von Bar, Christian, Clive, Eric (eds). 2009. Draft Common Frame of Reference. Full Edition. Munich, Sellier.

Wagner, Gerhard. 2006. Prävention und Verhaltenssteuerung durch Privatrecht. Archiv für die civilistische Praxis 206 (2/3): 352-476.

Wagner, Gerhard. 2010. Mandatory Contract Law: Functions and Principles in Light of the Proposal for a Directive on Consumer Rights. Erasmus Law Review 3 (1): 47-70. 
Westphalen, Friedrich Graf von. 2020. b2b-Plattform-Verordnung: Das AGB-Recht vor weitreichenden Veränderungen. Betriebs-Berater 11: 579-586.

Received: October 18, 2020

Accepted: January 12, 2021

\title{
Характеристика современного европейского договорного права
}

\author{
Райнер Шульце
}

Для цитирования: Schulze R. Characteristics of modern European contract law // Правоведение. 2020. Т. 64, № 2. С. 201-221. https://doi.org/10.21638/spbu25.2020.201

\begin{abstract}
Европейское договорное право недавно вступило в новую фазу развития в результате введения нового законодательства, отвечающего вызовам, связанным с цифровизацией, в том числе с поставкой цифрового контента и цифровых услуг. В то время как новое законодательство содержит несколько характеристик, которые отражают преемственность концепций, уже хорошо зарекомендовавших себя в европейском договорном праве, для учета специфических особенностей этих цифровых продуктов и способа их поставки потребовалось несколько нововведений. Законодательные меры будут играть ключевую роль не только в защите прав потребителей, но и в европейском договорном праве. Статья посвящена, в частности, двум новым «двойным» директивам: Директиве 2019/770 о некоторых аспектах, касающихся контрактов на поставку цифрового контента и цифровых услуг, и Директиве 2019/771 о некоторых аспектах, касающихся контрактов на продажу товаров. При рассмотрении основных особенностей этих двух директив в статье показано, как их новые и инновационные характеристики, отвечающие вызовам цифровизации, могут способствовать созданию современного европейского договорного права. Эти новые подходы в европейском законодательстве демонстрируют, что дальнейшее развитие договорного права сталкивается с проблемами, выходящими за рамки указанной области права. Таким образом, модернизация договорного права поднимает вопросы, которые в конечном счете должны быть направлены на прояснение общих особенностей европейского частного права в целом. Наконец, взаимосвязь между обязательственным правом, с одной стороны, и вещным правом или правом интеллектуальной собственности, с другой стороны, и, возможно, новое определение границ и взаимодействия между этими областями можно рассмотреть, если договорное право призна́ет данные в качестве актива, но не сможет гарантировать достаточную защиту этих активов только с помощью своих инструментов. Внедрение новых концепций, принципов и правил в области договорного права в развитие частного права в целом в соответствии с изменениями в «цифровую эпоху» остается важной задачей для законодательства и правовой доктрины в Европейском союзе и за его пределами.
\end{abstract}

Ключевые слова: договорное право, условия договора, потребительское право, защита прав потребителей, данные, цифровизация, право Европейского союза.

Статья поступила в редакцию: 18 октября 2020 г. Рекомендована в печать: 12 января 2021 г.

Шульце Райнер - д-р юрид. наук, проф., почетный доктор, Университет Мюнстера, юридический факультет, Германия, 48143, Университетская ул., 14-16; reiner.schulze@uni-muenster.de 